Проф. др Љиљана Марковић

Филолошки факултет

ljiljana.markovic@gmail.com

\title{
БАШТИНА НАРОДНЕ МУДРОСТИ КАО СНАГА КЬИЖЕВНОГ СТВАРАЛАШТВА У МОДЕРНИЗАЦИЈИ
}

Књижевно стваралаштво у периоду модернизације на размеђу 19. и 20. века, како у Србији, тако и у Јапану, одликује се значајним ослањањем на баштину народне мудрости, као неисцрпном исходишту снаге неопходне како би се велики узлет модернизације могао извести. Посматраћемо стваралаштво Петра Кочића кроз призму његових јапанских пандана, а посебно Акутагаве Рјуносукеа. Анализираћемо теме љубави према родној земљи, лепоти традиционалног, представи о жени, елементе сатире, ироније и хумора и друге елементе баштине народне мудрости.

Кључне речи: традиција, модернизација, народна мудрост, елементи народног наследја, иронија, сатира, хумор

Петар Кочић и Акутагава Рјуносуке имају доста додирних тачака како у биографском погледу, тако и у књижевно-стваралачком. Наиме, оба писца су живела и стварала на размеђу 19. и 20. века (Кочић је рођен 1877, а Акутагава 1892. године). Петар Кочић умире у 39 години (1916) у првој душевној болници на Балкану (данас Докйорова кула), која је за време кнеза Михајла Обреновића носила назив Дом за с ума сишавще, док 
Акутагава Рјуносуке извршава самоубиство отровавши се барбиталом и умире у 35. години (1927). Живот ова два писца био је обележен од најранијег детињства потпуним одсуством фигуре мајке. Мајка Акутагаве Рјуносукеа умире готово одмах након порођаја од последица душевне болести, а Кочић остаје без мајке када му је било само две године. Јапанског писца одгаја ујак са мајчине стране услед чега је и задржао мајчино презиме Акутагава, док се Кочићев отац закалуђерио и напустио родни дом и децу. Поред тога, оба писца су по завршеним студијама краће време предавали - Кочић предаје у гимназији у Скопљу, а Акутагава у оквиру Школе йоморскоі инженерстива у граду Јокосука краће време предаје енглески језик. Иако су остатак живота превасходно посветили књижевном стваралаштву, и Кочић и Акутагава су писали за новине које су за циљ имале не само уношење књижевно-уметничких новина, већ и промене друштвено-политичког типа.

Нажалост, живот обојице писаца окончан је нервним растројством услед бурних животних околности, као и друштвених и историјских преврата. Прибојавајући се да би могао завршити као његова мајка, Акутагава Рјуносуке одлучује да изврши самоубиство из страха да би могао полудети. У новели Зуйчаници из 1927. године описује своје нервно стање као полубунило-кошмар у којем му се континуирано привиђају зупчаници различитих димензија и наводи да му је живот постао неподношљив, те у његовом последњем делу Писмо gруїу (посвећено Кумеу Масау) отворено говори о самоубиству. За разлику од њега, Петар Кочић доживљава крај свог живота у Дому за с ума сишавще као период ослобођења од друштвених и политичких стега које су га читавог живота пратиле. Међутим, овде треба имати у виду и чињеницу да је крајем 19. века у европској књижевности, која је јасно извршила велики утицај и на српску и на јапанску књижевност тога доба, појам лудила био уско повезиван са стваралачким генијем, 
те се на њега није гледало као на потпуно негативан феномен. У том контексту, Карлсон наглашава да у Зуйчаницима „можемо препознати пројекције европских појмова лудог генија.“(Karlson 2009: 642) ${ }^{1}$

\section{Друштвено-историјске прилике} на територији Босне и Херцеговине и Јапана у процесу модернизације

Друштвено-историјске прилике између 19. и 20. века биле су изузетно тешке на територији Босне и Херцеговине. Годину дана по рођењу Петра Кочића, Аустро-Угарској је на Берлинском конгресу допуштено да окупира Босну и Херцеговину под условом да разреше унутрашња питања која су настала као резултат вишевековног ропства под Турцима. Босанске и херцеговачке буне које су претходиле ослобађању од османлијског зулума истакле су неопходност укидања феудалних односа и изузетно тешког положаја сељака-кмета. Шире гледано, ове буне су покренуле процес националног и политичког ослобођења, који је знатно успорен (али не и заустављен) аустро-угарском окупацијом. Нова власт чинила је све што је у њеној моћи да у корену сасече националистичка осећања код својих поданика и да наметне нове дажбине, тако да су услови живота убрзо постали гори него за време владавине Турака. Петар Кочић је представник генерације која је расла у оваквим условима окупације, али са усађеном, живом потребом да се избори за националну и политичку независност. Његова се дела стога често (понекад

1 Karlson, M. (2009). Writing Madness: Deranged Impressions in Akutagawa's "Cogwheels" and Strindberg's Inferno. Comparative Literature Studies, 46(4), str. 642. 
и погрешно) пре свега тумаче кроз призму друштвено-историјских и политичких прилика територије на којој је рођен. Кочићево чувено дело Јазаваи, ирреg суgом управо представља оштру критику тешке политичке ситуације и неправедног друштвеног поретка у Босни и Херцеговини на размеђу 19. и 20. века.

Премда је основну школу учио у манастиру Гомионици, гимназију у Сарајеву и Београду, а факултет у Бечу, чињеница да се родио у селу Стричићи у Босанској крајини је оставила неизбрисив траг у целокупном Кочићевом књижевном стваралаштву. Његово континуирано и оштро политичко ангажовање проистекло је управо из тог живог, сељачког осећања родне груде за коју се вреди борити и умрети. Стога је тема љубави према родној земљи заступљена у готово свим његовим књижевним делима и свакако чини потку његових текстова који су за циљ имали критику политичко-економске ситуације у Босни и Херцеговини. Из горе наведених разлога, Кочићев књижевни опус треба посматрати из опште-важеће, људске перспективе, а не у контексту искључиво друштвено-историјских прилика у Босни и Херцеговини тога доба, будући да су борба за национално и политичко ослобођење, љубав према родној земљи и критика лошег положаја сељака-кмета универзалне теме светске књижевности.

Друштвено-историјске прилике у Јапану које су претходиле књижевном стваралаштву Акутагаве Рјуносукеа, обухватају период пре Меиђи ресторације и мисао Касније Мито школе. Један од најважнијих мислиоца ове школе био је Аизава Сеишисаи. У својој чувеној збирци есеја Шинрон (Нове йезе), која се често назива и библијом јайанске моgернизације, Аизава 1825. године износи јапански приступ модернизацији и вестернизацији. У складу са његовим тумачењем, модернизација Јапана подразумева како прилагођавање западној цивилизацији и његовим 
мерилима економског и технолошког напретка, тако и неговање специфичног јапанског националног и културног идентитета. Овакав приступ омогућава очување традиционалних вредности Јапана уз истовремено формирање нове друштвене и културне парадигме под утицајем Запада. Наиме, у основи дела Шинрон Аизава нуди образложење за теорију Кокуйаи у оквиру које са једне стране предлаже оснаживање националног осећања у Јапану, а са друге укидање феудалне оданости клану Токугава.

Уколико изузмемо чињеницу да је ова теорија постављена на темељима преузетим из најстаријих писаних документа о Јапану - Кођикија и Нихонгија, односно митова о божанском стварању Јапана и a priori схватању да је јапанска нација супериорна у односу на друге, могу се повући бројне паралеле између друштвено-историјске климе каква је владала у Босни и Херцеговини и у Јапану на размеђу 19. и 20. века. Обе нације су биле претежно аграрне, а бориле су се за укидање пређашњег, феудалног уређења земље и застарелог друштвеног поретка. Осим тога, и Босна и Херцеговина и Јапан су се залагали за оснаживање националног осећања сматрајући га основним покретачем модернизације и економско-технолошког напретка, а не препреком.

Међутим, јасно је да постоји битна разлика између физичке окупираности територије каква је задесила Босну и Херцеговину од потенцијалне опасности која је претила Јапану услед снажних утицаја који су долазили споља. Уистину, ови страни, западни утицаји су водили убрзаној и на моменте готово неконтролисаној вестернизацији до тада у одређеној мери изоловане земље, али нису до сржи уздрмали јапански национални и културни идентитет. Једно од решења за успешну вестернизацију и модернизацију Јапана уз очување древних, традиционалних вредности земље излазећег сунца, садржано је y wakon-yōsai (和魂洋才) крилатици Јошикаве Тадајацуа - Јайански gух, зайаgна йехнолоїија, која се по први 
пут појављује 1867. године у делу Каика сакурон (срп. Пийана и йеме о йроїресу). С друге стране, Аизава Сеишисаи излаз из онога што се у конфучијанској анализи назива наију-їаикан (смртна комбинација унутрашње слабости и спољашње опасности) и моралног срозавања Јапана, види у моралном прочишћењу срца уз шинтоистичке обреде очишћења и окретању ка божанској фигури цара. Наиме, Аизава је сматрао да тек када се пробуди јака свест о националној припадности Јапанаца треба приступити брзом економском напретку утемељеном на одличном познавању западне науке и технологије која је великом брзином пристизала са Запада.

Нажалост, ситуација у Босни и Херцеговини није пружала могућност да се страним, аустро-угарским утицајима приступи споља, те је потреба за очувањем традиционалних вредности била још израженија. Један од начина да се национални и културни идентитет очува упркос бројним (а у случају Босне и Херцеговине и насилно наметнутим) страним утицајима јесте значајно ослањање на баштину народне мудрости, као неисцрпног исходишта снаге неопходне како би се национално ослобођење и велики узлет модернизације могао спровести у дело. Петар Кочић и Акутагава Рјуносуке су уз помоћ сатире, ироније и хумора успели да у кратким прозним формама сачувају оригиналне елементе баштине народне мудрости. Поређењем најзначајнијих дела ова два писца закључујемо да су поменути елементи универзалне природе, те да се могу пронаћи у књижевности различитих земаља.

Књижевно стваралаштво Петра Кочића кроз призму његовог јапанског пандана - Акутагаве Рјуносукеа

Књижевно стваралаштво Петра Кочића је богато кратким прозним формама, међу којима су најпознатије приповетке Кроз мећаву, Јаблан и Мрїуа. Главни јунаци 
Кочићевих прича углавном су сељаци који опхрвани различитим недаћама живе у селима Босне и Херцеговине међу идиличним природним лепотама Кочићевог родног краја. Међутим, приповетка Кроз мећаву нуди другачију слику природе, слику беспоштедне природе која главног јунака - простодушног српског сељака, Рељу Кнежевића оставља завејаног у снегу заједно са његовим братанцем Вујом. Победа природе над човеком у овој причи може имати и симболично значење, па се тумачити и као упорна, али неуспешна борба народа Босне и Херцеговине најпре против Турака, а потом и против Аустро-Угарске. У наставку ћемо дати осврт на једно од најпознатијих Кочићевих дела, сатиричну драму Јазаваи, иреg суgом, кроз призму књижевног стваралаштва јапанског писца Акутагаве Рјуносукеа.

Често називан „оцем јапанске приповетке“, Акутагава Рјуносуке у јапанској књижевности заузима слично место попут оног које Петар Кочић има у српској књижевности на размеђу 19. и 20. века. Као и Кочић, Акутагава је мајстор кратке прозне форме сатиричног стила, стила који је суштински модеран иако негује традиционалне елеменате који потичу из ризнице народне мудрости. Патрик О’Конор наводи да се „Рјуносуке Акутагава може сматрати јапанским Едгар Алан Поом, виртуозним писцем који је ушао у тамне углове људске душе и створио запањујуће, незаборавне ликове и ситуације које су одражавале оно што је у тим угловима пронашао.“(O’Connor 1986: 79)² Слично се може рећи и за Петра Кочића. Осим тога, оба писца се у својим срединама могу окарактерисати као политички и социјални револуционари. Они су борци против застарелих начела друштвено-економског уређења, који се истовремено супрот-

2 O'Connor, P. J. (1986). Recommended: Ryunosuke Akutagawa. The English Journal, Vol. 75, No. 7. str. 79. 
стављају насилно наметнутим спољашњим утицајима. Међутим, важно је напоменути да је за Акутагаву концепт књижевности „био основа свести о модерности која се дефинише као 'универзална', односно као свет у коме се растојање између јапанске и западне културе у великој мери укида."(Lippit 1999: 29)3

Горе поменуте сличности ова два писца дају основа за посматрање књижевног стваралаштва Петра Кочића кроз призму књижевног опуса Акутагаве Рјуносукеа. Осим тога, Акутагава се, „као и многи интелектуалци његовог доба, дубоко интересовао за културне традиције Европе“, (Suter 2013: 39) ${ }^{4}$ те се дела Петра Кочића и тематика којом се она баве могу посматрати и у том контексту.

Један од највећих писаца Таишо периода, Акутагава Рјуносуке стварао је своја најпознатија дела у доба када натурализам (као инхерентно мрачан и песимистичан књижевни правац - унеколико невешто пресликан из европске књижевности) губи примат најзаступљенијег правца у јапанској књижевности. Услед овакве ситуације, у Јапану се у овом периоду јављају бројни, нови књижевни правци, попут неоидеализма, који је настао под утицајем Лава Толстоја и старе кинеске филозофије, и неоромантизма на челу са Нагаи Кафуом. Поред Кикући Кана, Акутагава Рјуносуке је био један од кључних представника јапанског неореализма. Тематски близак опусу јапанског писца, књижевни опус Петра Кочића припада српском реализму и модерни. Треба и напоменути да се под утицајем књижевног критичара Хома Хисаоа и његовог нашироко дискутованог чланка $O$ нароgној уметиностии из 1916. године у Јапану јавља пролетерска

3 Lippit, S. M. (1999). The Disintegrating Machinery of the Modern: Akutagawa Ryūnosuke's Late Writings. The Journal of Asian Studies, 58(1), str. 29.

4 Suter, R. (2013). Grand Demons and Little Devils: Akutagawa's Kirishitan mono as a Mirror of Modernity. Journal of Japanese Studies, 39:1. str. 39. 
књижевност, односно раяничка книжевности (労働者文 学). Једна од најважнијих крилатица пролетерске књижевности јесте да књижевност мора припадати народу као уметност која је део народне културе и која из ње проистиче. Попут Петра Кочића, и Акутагава Рјуносуке је писао и за обичан народ, негујући притом традиционалне елементе баштине јапанске народне мудрости.

За својих тридесет и пет година живота, Акутагава Рјуносуке је написао преко две стотине приповетки и новела, које су преведене на многе светске језике, те је јапанску књижевност приближио оквирима светске књижевности. Његово књижевно стваралаштво се може поделити на три периода: први који се оквирно завршава 1920. године, други који траје до 1923. и трећи који почиње 1924. године и траје све до пишчеве смрти. У првом периоду стваралаштва, Акутагава разматра моралну и психолошку страну личности човека, а најпознатије приповетке ове фазе стварања су Нос (1915) и Рашомон (1915). Приповетку Генерал пише како би изнео оштар критички став о традиционалним самурајским вредностима и идеалима, и на тај начин указаје на неопходност модернизације и остављање застарелих начела у прошлости. С друге стране, само две године раније у причи Бал Акутагава исказује забринутост због претераног отварања Јапана према страним утицајима почетком Меиђи ере. Наиме, „Акутагава описује бал са становишта младе жене Акико, седамнаестогодишње ћерке припадника нове Меиђи елите.“(Rosenfeld 2000: 53) вор на једно страно виђење Јапана из пера француског писца Пјера Лотија, односно његових путничких мемоара из 1889. године и представља жељу да се понуди нова, модерна слика земље излазећег сунца.

5 Rosenfeld, D. (2000). Counter-Orientalism and textual play in Akutagawa's' The ball'('But l kai'). In Japan Forum (Vol. 12, No. 1, pp. 53-63). Taylor \& Francis. str. 53. 
Дела другог периода стваралаштва Акутагаве представљају критику нарави са фокусом на људске пороке, а пре свега егоизам. Тематика постаје искључиво савремена, а најчешће обрађиване теме овог периода су морал, религија и друштвена неправда. Јунаци приповедака из друге фазе стваралаштва су обични, мали, немоћни, сиромашни људи опхрвани проблемима, какви су рецимо у причи Ваїонети из 1922. Исте године Акутагава у Кини пише једну од његових најзначајнијих приповедака - У щумарку, у којој је позајмивши тему из збирке причи Хеиан периода Коюаку Моноїа-

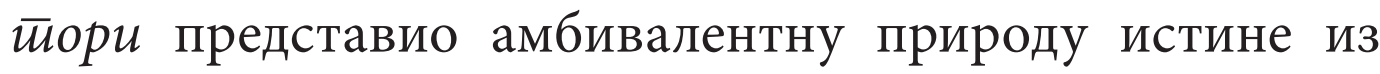
перспективе три књижевна лика - жене, разбојника и духа убијеног самураја. Наиме, Акутагава је желео да укаже на чињеницу да истина може изгледати потпуно другачије из перспективе друге особе. Ова приповетка је, између осталог, послужила као потка Акири Куросави за филм Рашомон, који снима 1950. године и за који добија Оскара годину дана касније.

Трећу стваралачку фазу Акутагаве Рјуносукеа одликује прелазак на друштвене теме посматране искључиво кроз савремену призму. Ова тематика је заступљена у његовим есејима Речи йиімеја и Белешке Текоgо. Међутим, за сагледавање Петра Кочића кроз призму књижевног стваралаштва његовог јапанског пандана Акутагаве Рјуносукеа можда је од највећег значаја Акутагавина новела У земљи воgених (Карра) објављена 1927. године. Писац новеле користи елементе јапанске митологије и главног јунака смешта у земљу капа, односно у свет бића која живе у води и на алегоријско-сатиричан начин представља савремено јапанско друштво, државно уређење, друштвене односе, религију и културу.

Премда Кочић у делу Јазаваи йpeg суgом не посеже за митолошким бићима, већ користи лик Давида Штрбца који је уистину и постојао, и он попут Акутагаве 
у новели У земљи воgених радњу свога дела смешта у скучен простор (суднице) како би на сатиричан, али и на духовит начин дао анализу друштва Босне и Херцеговине под окупацијом Аустро-Угарске на размеђу 19. и 20. века. Оштро критикујући аустро-угарско правосуђе, Кочић „ће са пуно хумора [...] и помоћу разних стереотипа исмејати аустроугарску бирократију и кратковидост закона и суда, оспоравајући им сваки модернизацијски значај“, (Vervaet 2009: 476) 6 бирајући притом домишљатог сељака Давида Штрбца за главног јунака. Лукавост овог српског сељака сличи суровој сналажљивости главног јунака Акутагавине приповетке Рашомон. Ова приповетка говори о моралној дилеми главног јунака, који се „бори за живот чекајући gа киша ӣре-

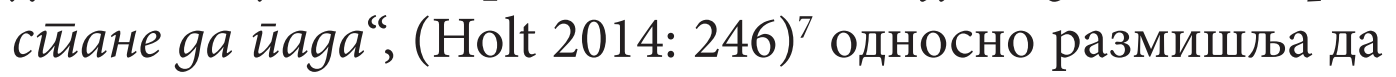
ли би био у стању да краде како не би гладовао. Угледавши старицу како сече косу мртвих људи, који су бачени код јужне капије Кјотоа - Рашомон капије, он је најпре згађен, а затим саслушавши оправдање старице која тврди да је жена чију косу сече преварила велики број људи за живота продајући им месо змије уместо рибљег, одлучује да опљачка старицу и узме јој одећу с леђа. Прича има поучан карактер и спада међу драгуље баштине јапанске народне мудрости. Шире гледано, поука приповетке Рашомон је и универзалног типа и може се применити на читаво човечанство. Кочићев Јазаваu, ūpeg суgoм носи у себи нешто од те мудрости. Наиме, јасно је да се намера Давида Штрбца да се јазавац осуди због крађе заправо односи на аустро-угарске вла-

6 Vervaet, S. (2009). 'Naš car ima za svašta zakon': kolonijalna modernost i nacionalni identitet u bosanskohercegovačkoj književnosti austrougarskog razdoblja. SLAVISTICNA REVIJA, 57(3), str. 476.

7 Holt, J. (2014). In a Senchimentaru Mood: Japanese Sentimentalism in Modern Poetry and Art. Japanese Language and Literature, 48(2), str. 246. 
сти, које не само што нису укинуле намете који је народ Босне и Херцеговине плаћао за време турске владавине, већ су увеле и нове дажбине не оставивши сељацима другог избора него да буду лукави и домишљати како би преживели.

\section{Теме из ризница народне мудрости у књижевном стваралаштву Петра Кочића и Акутагаве Рјуносукеа}

Тема љубави према родној земљи је једна од најзаступљенијих у књижевном опусу Петра Кочића. Задојен стиховима јуначких песама и песничког епа Горски вијенаи, од најранијих дана, Кочић је неоспорно осећао нераскидиву повезаност са својом земљом и народом. Стога његова дела најчешће „говоре о страдању српског народа под владавином аустро-угарске монархије у Босни и Херцеговини. Може се рећи да је Кочић читав свој живот и своје књижевно стваралаштво посветио борби, борби за национално-социјално ослобођење и борби за српски језик“. (Savanović 2010: 4) ${ }^{8}$ Године 1985, Владимир Јовичић у сличном тону наводи да је „највећи дио стваралаштва Петра Кочића у знаку његовог опредељења за слободу, уједињење српства и за социјалну правду“. (Jovičić 1985: 270)9 Патриотски жар његовог књижевног стваралаштва најјаче се распламсао за време студија у Бечу, где Кочић почиње да пише своја прозна дела. „Његова прва прича Туба (1900) започиње идиличном сценом на селу, али убрзо прелази на проблем [...] младог љубавног пара, Тубе и њеног дечка Благија (Благоје). Благија регрутује аустроугарска војска и он умире

8 Savanović, N. (2010). Karakteristična leksika Kočićeve proze. str. 4.

9 Jovičić, V. (1985). Srpski pisci, Prosveta, Beograd, str. 270. 
од мистериозне болести у војном логору у Грацу. [...] У тренутку када при крају приче Туба јецајући узвикује речи Ümete nas Graz (Уништи нас Грац), чини нам се да не оплакује само своју судбину, већ судбину читаве Босне“. (Butler 2010: 2) ${ }^{10}$ Овај жар да се одбрани оно што је есенцијално национални дух и традиција једног народа присутно је и у делима Акутагаве Рјуносукеа.

Тема љубави према родној земљи у делима Петра Кочића и Акутагаве Рјуносукеа уско је повезана са поштовањем које исказују за лепоту свега онога што је традиционално. Једна од битних тема је и представа о жени. Уколико имамо у виду да су оба писца рано остала без фигуре мајке, потпуно је разумљиво да је представа жене у неку руку искривљена. У делима Акутагаве Рјуносукеа жене су често приказане као доминантне, себичне и склоне превари. Након што је усвојен од ујака, Акутагава је био под јаким утицајем његове тетке Фуки, агресивне жене која ће га читавог живота контролисати. Њен лик му је највероватније послужио као инспирација за причу Кеса и Морийо из 1918. године. У овој причи Кеса је млада, удата жена која покушава да контролише свог љубавника Морита у одлуци да убије њеног мужа. Осетивши да Морито није сигуран да ли осећа мржњу или љубав према њој, те да самим тим није више под њеним јаким утицајем, Кеса одлучује да живот оконча самоубиством.

У делима Петра Кочића представа жене је ипак нешто позитивнија него код Акутагаве Рјуносукеа. Премда у делу Јазаваи, ӣpeg суgом Давид Штрбац описује своју невенчану жену као наопаку, злочасту и џандрљиву удовицу која се три пута удавала и која га је у више наврата тукла, он истовремено каже и да је паметна и учена жена од ӣoйовске лозе, а након тога и да је слатка и драга. У при-

10 Butler, T. J. (2010). Between East and West: Three Bosnian Writer-Rebels: Kočić, Andrić, Selimović. Spirit of Bosnia/Duh Bosne, 5(4). str. 2. 
повеци Mрїyg Петар Кочић за главног јунака бира младу девојку бујне лепоте - Мргуду која својим изгледом изазива завист код жена у селу. Затрудневши са момком Миком, она га осрамоћена чека да се врати из рата. Након што је младић одбија и говори да ће оженити Ђурђију, Мргуда одлучује да се обеси. Иако је закључак да не треба оштро судити другима, оваквим трагичним завршетком приче Кочић се ипак залаже за пут врлине и морала и на најстрожи начин кажњава посрнулу јунакињу. Осим тога, преостали женски ликови оговарају Мргуду од почетка па до краја приче, оптужујући је чак да је призвала временске непогоде попут града након што се обесила, те суштински представљају негативне ликове у књижевном свету Петра Кочића. У складу са тим је и чињеница да Кочић мушком лику - старцу Чочорику даје прилику да на крају приче изнесе суд да је Мргуда погрешила, али и да је свој грех окајала.

Књижевно стваралаштво Петра Кочића и Акутагаве Рјуносукеа обилује елементима сатире, ироније и хумора. Ови елементи су преузети из ризнице народне мудрости која се вековима преносила усменим путем како у Босни и Херцеговини, тако и у Јапану. Рад је имао за циљ да приближи два писца који су стварали у потпуно различитим срединама и друштвено-историјским приликама, али који су своју инспирацију црпели из баштине народне мудрости која је у својој бити неминовно универзална.

\section{Литература:}

Butler, T. J. „Between East and West: Tree Bosnian Writer-Rebels: Kočić, Andrić, Selimović“. Spirit of Bosnia/Duh Bosne, 5(4), 2010. Gerow, A. A. „Te Self Seen As Other: Akutagawa and Film“. Literature/Film Quarterly, 23(3) (1995): 197-203. 
Holt, J. „In a Senchimentaru Mood: Japanese Sentimentalism in Modern Poetry and Art“. Japanese Language and Literature, 48(2) (2014): 237-278.

Hughes, H. J. (2000). „Familiarity of the Strange: Japans Gothic Tradition". Criticism, 42(1) (2000): 59-89.

Jovičić, V. Srpski pisci, Beograd: Prosveta, 1985

Karlson, M. „Writing Madness: Deranged Impressions in Akutagawa's "Cogwheels" and Strindberg's Inferno". Comparative Literature Studies, 46(4) (2009), 618-644.

Kurachi, T. „Akutagawa Ryünosuke and Spiritualism“. Comparative Literature Studies, (1991): 259-270

Lippit, S. M. „The Disintegrating Machinery of the Modern:Akutagawa Ryūnosuke’s Late Writings“. The Journal of Asian Studies, 58(1), (1999): 27-50.

Milojković-Djurić, J. „The Eastern Question and the Voices of Reason: Austria-Hungary, Russia, and the Balkan States, 18751908“ (No. 592). East European Monographs, 2002

O'Connor, P. J. Recommended: Ryunosuke Akutagawa. Te English Journal, Vol. 75, No. 7. (1986): 79-80.

Rosenfeld, D. „Counter-Orientalism and textual play in Akutagawa's' Te ball'('But 1 kai')“. In Japan Forum. Vol. 12, No. 1 (2000): 53-63

Savanović, N. Karakteristična leksika Kočićeve proze. 2010

Suter, R. „Grand Demons and Little Devils: Akutagawa's Kirishitan mono as a Mirror of Modernity“. Journal of Japanese Studies 39:31 (2013)

Swann, T. E. „Futari Komachi: Akutagawa Ryunosuke“. Monumenta Nipponica (1968): 485-495.

Tsuruta, K. „Akutagawa Ryunosuke and I-novelists“. Monumenta Nipponica, (1970) 25(1/2), 13-27.

Vervaet, S. „Cultural politics, nation building, and literary imagery: towards a post-colonial reading of the literature (s) of Bosnia-Herzegovina 1878-1918“. KAKANIEN REVISITED, (28/12) (2009), 1-15.

Vervaet, S. „Naš car ima za svašta zakon’: kolonijalna modernost i nacionalni identitet u bosanskohercegovačkoj književnosti austrougarskog razdoblja“. SLAVISTICNA REVIJA, 57(3) (2009): 467-481 
Ljiljana Marković

\section{HERITAGE OF THE NATIONAL POWER OF WISDOM AS LITERARY CREATIVITY IN MODERNIZATION}

\section{Summary}

Literary production in the period of modernization between the nineteenth and twentieth centuries, both in Serbia and in Japan, characterized by significant reliance on inheritance of folk wisdom, as well as the origin of the inexhaustible strength necessary to be a great boom that modernization could do. We will observe the creativity of Petar Kočić through the prism of his Japanese counterparts, especially Akutagawa Rjunosuke. We will analyze topics of love for the native land, the beauty of traditional image of the woman, the elements of satire, irony and humor and other elements of the heritage of folk wisdom.

Key words: tradition, modernization, folk wisdom, elements of folk heritage, irony, satire, humor. 